\title{
Military Logistics Efforts during the Vietnam War Supply Chain Management on Both Sides
}

\author{
Hermann Gruenwald \\ Burapha University International College Chonburi, Thailand \\ Gruenwaldh@Yahoo.com
}

\begin{abstract}
This paper analyses the role of military logistics operations during the Vietnam War. It looks at the technical and strategic role of logistics, and the physical obstacles that had to be overcome in Vietnam. The US had highly sophisticated war machinery that was deployed in a country that lacked not only the transportation infrastructure (roads, ports, airports) but also had extreme terrain and climate conditions. On the other hand the Vietnamese had a well-oiled supply chain which often was carried on bicycles and literally on the backs of humans not only along the Ho Chi Minh Trail but throughout the north and south of Vietnam. On the US side helicopters played an important transportation role substituting land transport with air transport. The war effort escalated so rapidly that there was literally no time for logistics advancement operations and prepositioning of assets which resulted in a parallel run of war fighting and logistics operations. Naval operations had to provide their own landing crafts due to the lack of deep seaports with adequate lifting equipment. At the same time airlifts required runways and aircontrol facilities which needed to be provided by the US. Even the US Department of Defense (DOD) food supply chain was supported from abroad while local war fighters could live off the land. The Vietnam War logistics effort reached over to neighboring countries, and Thailand played an important role with its naval and airbases close to Sattahip, U-Tapao and northern parts of Thailand. There are valuable lessons to be learned for both military logistics as well as private sector supply chain management.
\end{abstract}

Keywords: Military logistics, supply chain management, Vietnam War

\section{Introduction}

This paper explores the military logistics issues during the Vietnam War. It looks both at the North Vietnamese logistics efforts of the Viet Cong (VC) and the People's Army of Vietnam (PAVN) also called the North Vietnamese Army and compares and contrasts them to those of the US and the South Vietnamese This paper has been written from a logistics standpoint and is less focuses on military strategy even so they go hand in hand and at times are hard to be viewed in isolation. This second Indochina war as the Vietnam War is referred to in the history books escalated over the years and started as a conflict. With the years the rules of engagement have changed which had severe impact on the war effort and the success and failures. It is difficult to go back in history and analyze what if and talk about lost opportunities. The pitfall was that the US found themselves involved in a war for which it did not have the time to build up logistics capacities. The war fighting and built up of logistics had to take place at the same time which imposed severe hardship on the logistics efforts. Vietnam as a country is extremely diversified both in culture, climate and terrain it stretches more than 2,000 $\mathrm{km}$ from the south to the north, with extreme high and low elevations. Where low lying areas are subject to heavy floods and war had to be literally fought in the mud which takes a great tall on heavy equipment and trucks. A dense tropical jungle often referred to as triple canopy does not even provide a landing space for timely helicopter support. On the other side the extreme mountainous conditions did not provide for roads wide enough for heavy trucks to run at a reasonable speed. The climate is quite different from the hot south to the cold north both in terms of climate and people. The Vietnamese effectively used propaganda in the fight against the US to win the support of their people and portrait Vietnam often in form of female images as victims. Everyone remembers the image of the napalm bomb victims running, and are less familiar with the various North Vietnamese military forces the full-time soldiers of the Viet Cong were referred to as the "Main Force" (Chu Luc). From a logistics standpoint the National Liberation Front (NLF) played an important role as it was created to encourage the non-communist general population to support the insurgency in South Vietnam (Prados, 1998). 
Figure 1: Vietnam War Time Map from Maps.com

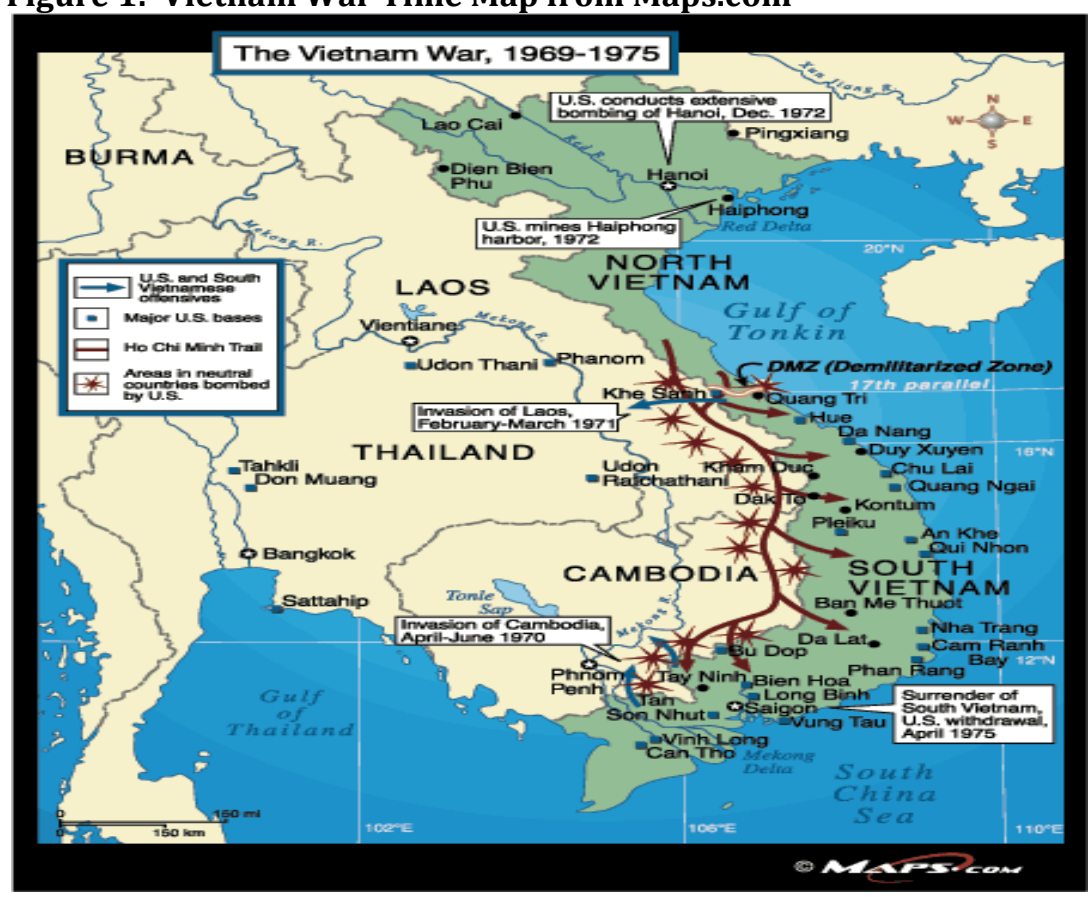

\section{Methodology}

This paper is written as a historic account of the logistics efforts during the Vietnam War. The historical nature of this paper relied on secondary literature and historical archive sources. Some of the great resources were the US military logistics community, with their logistics websites for army, navy and air force. The YouTube videos and in particular the one on army logistics in Vietnam (Vietnam War: Army Logistics in Vietnam - United States Army) is a great source for statistics and images. Another great video is "Vietnam War Railroad Logistics 1967 US Army" and "Logistics in Vietnam - The Big Picture"; one has to be aware that this was US military propaganda material at the time. The Texas Tech Vietnam Center was another great resource for catalogued sources and oral accounts. One has to be aware that these accounts were written over several decades and therefore are also indicative of the times ant their context. The researcher is the major instrument and everything is written from a perspective that reflects those values and experiences of the author. There is a time value to history in retrospect what we see today as tragedy will be viewed in twenty as comedy. Historical studies are comparative studies looking for patterns in history and there are certainly patterns that can be helpful for logistics and military logistics in particular. This study also includes the self reported perceptions of Vietnam War veterans and scholars from both sides of the fence. These views are certainly not neutral as they heavily rely on ideology, thus North Vietnamese still exists that the focus of this war was not to expand communism and Marxists ideology but a nationalistic focus uniting Vietnam in one country and one identify. Again there are parallels between North and South Vietnam as well as East and West Germany. There reasons for their division may be similar or the same as pointed out earlier it depends on the micro or macro view and what is the real motive behind it. In the case of Vietnam the division of the country was a pattern used to dissolve colonialism in Asia. But at the same time the US got increasingly concerned about the spread of communism in South East Asia in Cambodia, Laos and Vietnam. One has to be careful when looking at historical archives and documents and how the Vietnam war was portrayed in the movies such as Good Morning Vietnam, Air America, MASH, Jumbo Drop, JFK, Apocalypse Now, Full Metal Jacket, these movies provide interesting logistics scenes, the historical facts may not always be correct abut provide interesting character images of the war and in particular the logistics efforts and the equipment used. 
Figure 2: US Army in a staging area $80 \mathrm{~km}$ north-east of Saigon

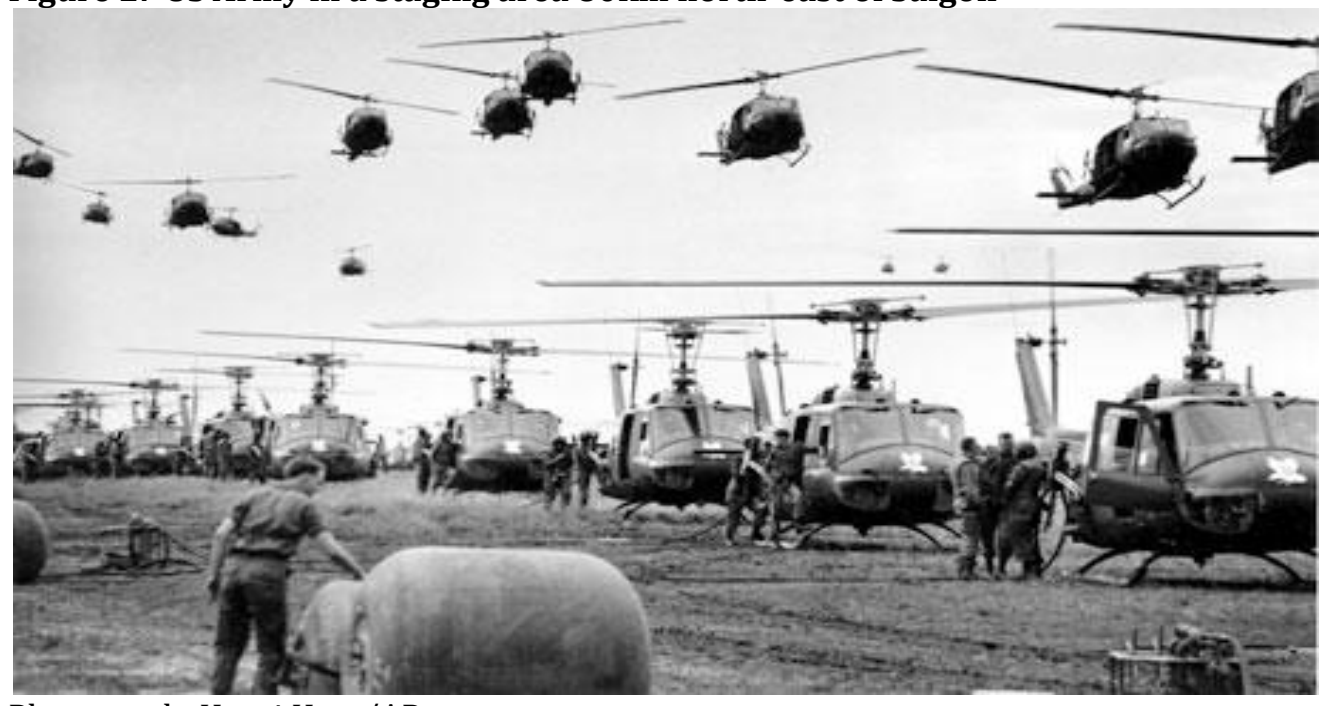

Photograph: Henri Huet/AP

\section{Military Logistics}

To understand military logistics one has to provide a definition first, as most people don't have a clear understanding of what logistics is. When talking to none native speakers they often confuse linguistics' with logistics. Logistics is more than transportation and warehousing, it deals with supply chain management (SC) getting the right stuff in the right amount to the right people at the right time. So it is important to forecast demand. This has been a problem in the Vietnam War as initially it was seen as a minor conflict with limited demand which could be provided through airlift capabilities. But as the conflict increased the amount of war material and support material escalated the US troops roughly needed ten times the amount of material the Vietcong were consuming as the Vietcong could live off the land and used their limited weapon systems very effectively. The US had a large demand not only for weapons to do large scale bombing and attacks of supply lines and heavy losses on weapons and equipment that were often unsuitable for the terrain and climate. The US war fighters also required food and drinks to be shipped in as well as personal hygiene products. The Vietcong often portrait the US soldiers to go home to their cozy beds and female companions after a day in the front line. Again one has to be careful about the sources and distinguish between the facts and propaganda. Certainly the live access was true for some higher ranking officers and supply line officers. One has to remember war is like the movies the best seats are in the back of the house. While troops stationed in Saigon may have a great time at the beginning, soldiers in the trenches fighting in rice fields with nothing in plenty but rain certainly had another impression. But what it is interesting that the American access often flew into the hands of the Vietcong either through capture or corruption. South Vietnamese officers may have sold supplies and even weapon systems to Vietcong for self enrichment, so the north has no real shortages if they really wanted something. Naturally the North was less concerned to provide their soldiers with all the creature comfort available. This meant that these items did not have to be shipped and did not impact the supply chain.

So one way of optimizing logistics is to reduce the demand on the supply chain. The Viet Cong was engaged in mobile guerrilla warfare and did not have to deploy large quantities of heavy artillery or tanks. Except for siege battles such as the one at Khe Sanh and across the Demilitarized Zone (DMZ). After the Easter Offensive of 1972 the VC shifted to conventional warfare which reached his high point in the final conventional campaign in 1975 at that point the US lost air superiority and the VC/NVA used Sovietsupplied heavy $122 \mathrm{~mm}$ and $130 \mathrm{~mm}$ guns that outranged the ARVN and American forces (Kane, 2001). Even so the US has highly effective weapon systems which could deliver an effective strike but often the target could not be positively identified. The US were fighting Charlie but Charlie was hard to be seen and detected. Another interesting military logistics topic is the transport of troops. The US in their convoys mixed troop and material movements which ended up being costly in terms of lives and material lost. The injured were evacuated to MASH hospitals of which were 18 scattered throughout Vietnam via Jeeps which were modified to be ambulances, armored personnel carriers marked with a red cross and naturally the Bell Huey Helicopter. The average time lapse from being wounded to hospitalization was 
one hour. Medevac helicopters flew nearly 500,000 missions and airlifted 900,000 patients of which half were Americans. Military Mortuary Affairs is another chapter of military logistics over 2 million people lost their lives in the war. One in 10 Americans served in Vietnam were either wounded or killed. Human remains were gathered from the battlefields and airlifted to the morgue in the field were there were boxes with arms and legs which were added to bodies with missing limbs that were shipped to the US in metal caskets. Later it was found that the embalming in country let to loss of body fluids during transport and was not continued in later wars. Also the identification of the deceased took a turn for the better at the U.S. Army Central Identification Laboratory, Hawaii

- 352 Billion US Dollars spent on the war.

- 760,000 tons of supplies arrived each month.

- 10 million field rations were consumed each month.

- 71,000 tons of ammunition was expended each month.

- 124,537 B57 missions

- 1,633,035 tons of ordnance dropped

- 18 B52S were lost to enemy action with

- 13 B52S lost in collisions and accident!

- 750 Aircraft (Fixed Wing) were lost in Vietnam

-12,000 helicopters saw service in Vietnam (all services)

- 4,865 Helicopters were downed by Communist ground fire

- 5,250,000 cost per helicopter

- 2.59 million Americas saw service in Vietnam

-3,500,000 acres of Vietnam was sprayed

- 19 million gallons of Defoliants the effects that will last 100 years.

- 303million liters of petroleum products were consumed each month.

- 33,450hectares of airfields were paved

-18,000 hectares of covered and open storage facilities were built

- 14,150 cubic meters of refrigerated storage created

- 4,740 km of roads built

- 4,600 meters of bridges constructed

- 15 large fortified bases were built in Vietnam

-10,000.artillery rounds expended in one day by the US in Vietnam

- $\$ 100$ Cost per artillery round

- $\$ 1,000,000$ Cost per day for artillery fire

- $\$ 30,000$ Cost of one sortie for a B-52 bomber

- $\$ 3,000,000,000$ of aid provided to North Vietnam by the

- Soviet Union and China

Left behind at the end of the war

- 550 light and medium tanks.

- 1,200 Armored Personnel Carriers (APC)

- 80 small ships and landing craft.

- 1,000 aircraft including 200 fighters and ground attacks aircraft.

- 100 transport aircraft and 500 helicopters

Table 1: Vietnam War Statistics

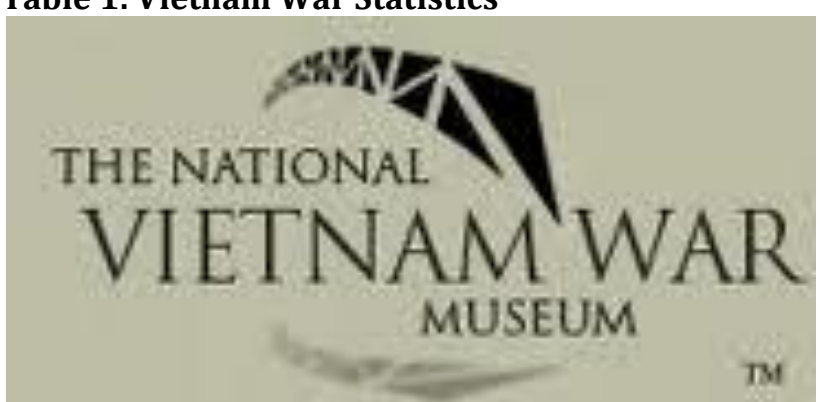

Source: http://www.103fieldbatteryraa.net/documents/74.html 
Land: The terrain of Vietnam defined land transportation by road and rail. The railroad has been a major artery between the north and south. This has been mode of transport than could be easily interrupted on both sides of the demilitarized zone. US bombing runs successfully hit the railroad in the north. Only the impact of interruptions were limited for the Vietcong as they relied less on the rail connection and only transported material and no troops via rail. The North Vietnamese had an effective system of female and old men and children who would repair the damages to the track in record time. It is also interesting to note that the Vietnamese have a rail track with three (3) rails which allows for two gages to be used. The track from Saigon to Hanoi was a single track which meant that trains could run in only one direction at a time and had to be switched at stations. The length of the switch track was the limiting factor for the length of the trains to be used. The track was and still at this time has not been electrified which means only coal and diesel engines could be used. Also the base for the track was at times less than staple especially after heavy monsoon rains. Which meant that there were so called LA langsam fahrstellen were only reduced speed could be used. The track was inspected daily by railroad workers walking the track and looking for failures in the railroad ties and breaks in the track. Interesting enough modernity brought the rail to Vietnam under the French and the rail system was well developed with train stations and protected railroad crossings.

There were literally thousands of bridges of various length from only a few meters to a few hundred meters which crossed creeks as well as rivers and valleys. The bridge over the red river was the longest one. Bridges were required for the railroad as well as the roads. The Vietcong used bridges sparsely and had a technique to built bridges under water so that they could not be detected by US bombers. The bridges were also temporarily replaced by river ferries and roads built on old oil tons. The North Vietnamese also had road crews which would repair bomb craters in roads while using bomb craters next to the road as ponds to bread ducks for their meat and eggs. On the other side the camouflage efforts of the North Vietnamese were outstanding they created 2,000 km of camouflaged roads and trails making transportation possible without immediate detection by US aircrafts and troops (Heiser, 1974). The US Jeep is another symbol of the Vietnam war many soldiers feel that the hummer is not a suitable replacement and the hummer certainly would not be effective in the Vietnamese terrain. US Jeeps are still in use in Vietnam the same as the old trucks and caterpillar equipment. This created a large demand for spare parts after the war and in particular modern times. The spare parts were purchased through Thailand due to the US embargo. The three modes of land transport include rail, road and pipeline. The Vietcong had a sophisticated pipeline system which was used to transport fuel as well as water. A more hybrid mode was the use of hovercrafts by the US to cross water and land in an efficient but costly matter which spare parts hart to come by. Spare parts and repair logistics were another major issues in the Vietnam War.

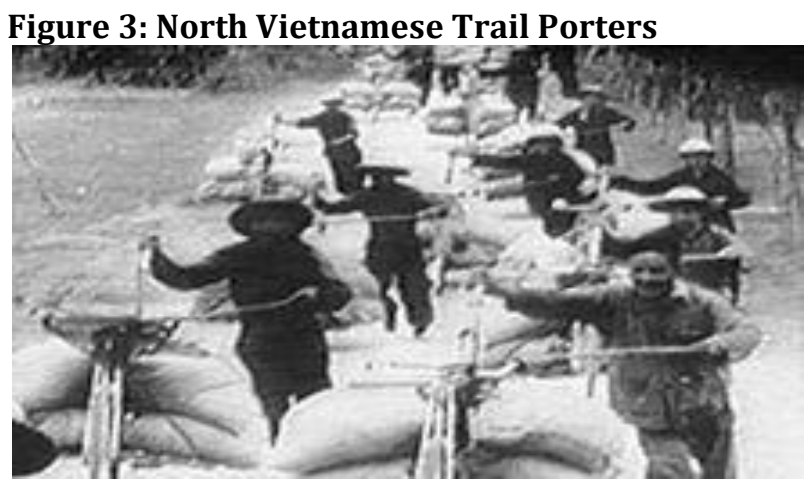

Source: http://en.wikipedia.org/wiki/Viet_Cong_and_Vietnam_People's_Army_logistics

Water: Water was the transport artery of choice for both North and South Vietnamese as the road system was limited and water occurred naturally and connected villages through streams, rivers and canals between rice paddies. Small boats could easily navigate these inland waterways. One has to remember this has been before global positioning systems (GPS) and navigation for US navy and army riverine forces was very difficult in an area which was overgrown by vegetation without major landmarks. Even the Mekong delta was difficult to navigate with all its side arms which were familiar to the locals and easy to ambush. Besides these inland waterways there was the importance of the ocean. Vietnam has over $3,000 \mathrm{~km}$ of coast line which made the country easily accessible by sea. $98 \%$ of all the cargo shipped to Vietnam arrived by sea (Hooper, 1972). The problem however was that there was insufficient logistics 
infrastructure for us naval forces to load and unload Major Ocean going vessels. Vessels used by US navy were Panama class size with a length over 200 meters, and a summer line often in excess of 12 meter which meant that the ports in Vietnam were not deep enough to allow docking and the cargo had to be littered to smaller ships just off shore which made for easy target for sabotage and MIG attacks. The US started to ship truck mounted cranes for loading purposes there were very few heady duty stationary lifting equipment at the ports still today these American truck mounted cranes are used in Vietnam in ports like Nhatrang and Hoian. Hoinan is fairly shallow port with a river delta and connections to the hinterland. Nhatrang had been developed by the US as a major port which actually is a number of smaller port facilities separated by a few kilometers (Schaff \& Fifield, 1963).

Hue also has a port but the city lays a few km back same as in Saigon which was and is the buzzing metropolis but too far south for military activities at the beginning of the war. The naval support ships, aircraft carriers and amphibious forces played an important role in the Vietnam war on the side of the US they delivered the majority of supplies to Vietnam. The riverine warfare forces patrolled the Mekong delta with swift boats and river patrol boats and delivered supplies up river through this so called "small boat navy" (Cutler, 1988). There was a special form of water transport on the Vietcong side they used canoes and small house boats where the owner of the boat lived on the boat. Besides rafts which consisted of logs tied together there unmanned vessels, which were actual vessels or empty oil barrels which were filled to their buoying capacity and sealed there were allowed to float down river were they were fished out of the water at various rotating landing points (Gargan, 2002).

Figure 4: Photograph VA002500, 1970, Douglas Pike Photograph Collection, The Vietnam Center and Archive, Texas Tech University

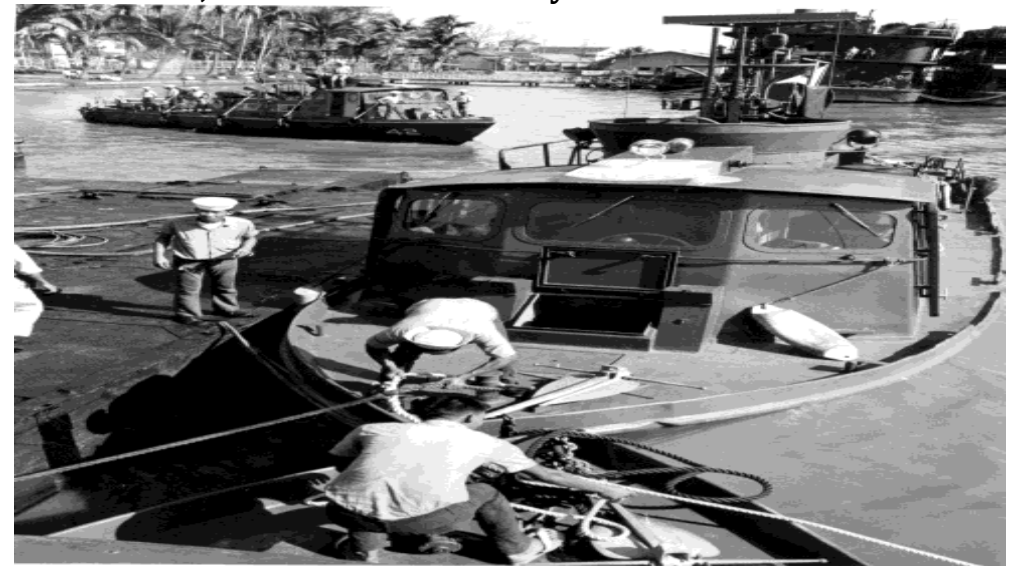

Source: http://www.vietnam.ttu.edu/virtualarchive/items.php?item=VA002500

Air: The US certainly had air dominance with its bombers and would have been able to bomb Hanoi to the ground. But the rules of engagement changed over the years and even $10 \mathrm{~km}$ around Hanoi were off limits to American pilots. The US military flew 1,899,688 sorties and dropped 6,727,084 tons of bombs on Indo China, compared with the 2,700,000 tons of bombs dropped on Germany during World War II. (Henderson, 2008).The Viet Cong was very well aware of the US rules of engagement limiting bombing runs. The US also did not fly attacks against Russian and Chinese supply chain measures delivering cargo by air and sea. Another interesting and still highly denied fact is that the Vietnamese were allowed to use airbases in bordering China which again were off limits to US attacks thereby guaranteeing an uninterrupted supply line for weapons and supplies. MIG fighter planes and air defense systems of the north were very effectively used to shoot down American airplanes and thereby interrupting the supply chain. The Americans also had airbases outside of Vietnam mainly in Thailand, Japan, Guam and Hawaii. Thailand airbases in U-Tapao and Issan played a major role in the supply chain. These bases were within minute's airtime of Vietnam flying either over Cambodia or Laos. Therefore the airspace over Cambodia and Laos was important to be kept safe. There was no war in Laos and no us forces in Laos as Richard Nixon declared on TV. Off the record there were the infamous logistics operations of Air America supporting the war effort by delivering goods in the Golden Triangle Region and supporting activities in Lao. These operations were taking care of by small aircrafts like the DC 10 which could land and takeoff from short unpaved landing strips. 
The real work horse of the Vietnam War was the Bell Helicopter the cavalry replaced its horses and trucks with whirly birds as they call the helicopter in the slang expression. These Hueys were often flown by army pilots with little experience who just learned to fly before coming to Vietnam and enhanced their skills by doing. This just in time (JIT) approach took its toll on equipment and pilots. As portrait in the movie JFK some even hold to the conspiracy theory that John F. Kennedy was killed in order to continue the Vietnam War, as after Kennedy's death Lyndon B. Johnson (LBJ) governor of Texas became president. And who benefited from the war in Vietnam the defense industry and namely Bell helicopters which were based in Dallas Fort Worth (DFW). One can disagree on this but the fact is that Bell helicopter is inseparable from the Vietnam War and will always be an icon of this war, such as the Apache is of modern warfare of the 21th century. The infamous photo of the Bell helicopters evacuating the US embassy during the fall of Saigon. Airlifting US personnel and Vietnamese from the US embassy in the center of Saigon to the US naval vessels. The DC10 and B52 bombers are equally icons of this time. While the B52 could deliver large amount of ordinance to bomb supply lines and to erase large part of the tropical vegetation to make the targets more visible. The Vietnam War was not a war against the Vietnamese but against the country a terrain and climate hard to beat.

Table 1: Major US Air Force Bases in Thailand

Don Muang Royal Thai Air Force Base

Nakhon Phanom Royal Thai Navy Base

U-Tapao Royal Thai Navy Airfield 1967 construction start

Ubon Royal Thai Air Force Base

Source: http://www.history.navy.mil/docs/vietnam/high5.htm

Table 3: Major US Air force Bases in South Vietnam

Bien Hoa Air Base, 1961-1973

Major USAF unit: 3d Tactical Fighter Wing, 1965-1971

Binh Thuy Air Base, 1965-1971

Major USAF unit: 632d Combat Support Group, 1966-1971

Cam Ranh Air Base, 1965-1972

Major USAF units: 12th Tactical Fighter Wing, 1965-1970; 483d Tactical Airlift Wing, 1970-1972

Da Nang Air Base. 1961-1972

Major USAF unit: 366th Tactical Fighter Wing, 1966-1972

Nha Trang Air Base, 1966-1971

Major USAF unit: 14th Air Commando/Special Operations Wing, 1966-1971

Phu Cat Air Base

Major USAF units: 37th Tactical Fighter Wing, 1966-1970; 12th Tactical Fighter Wing, 1970-1971

Pleiku Air Base, 1965-1971

Major USAF unit: 633d Special Operations Wing, 1968-1970

Phan Rang Air Base, 1966-1972

Major USAF unit: 35th Tactical Fighter Wing, 1966-1971

Tan Son Nhut Air Base, 1961-1973

Major USAF unit: 377th Air Base Wing, 1966-1973

Tuy Hoa Air Base, 1966-1970

Major USAF unit: 31st Tactical Fighter Wing, 1966-1970

Source: http://www.history.navy.mil/docs/vietnam/high5.htm 
Figure 5: Bell UH-1 Huey from the 161st Assault Helicopter Company

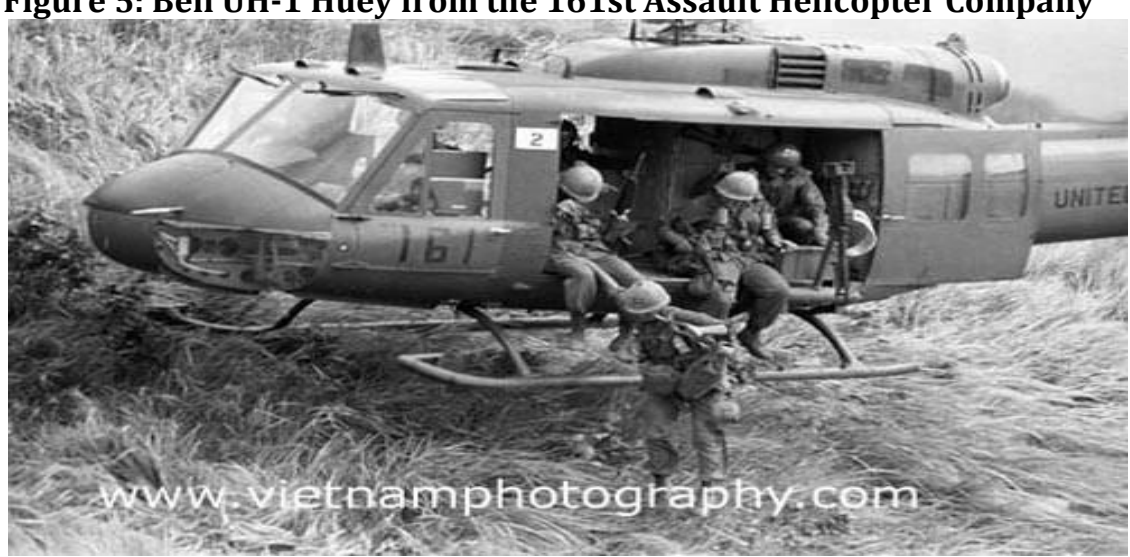

Source: Vietnamphotography.com

Discussion: The terms discussion and conclusions may be used interchangeable. As any conclusion in terms of history deserves discussion. A topic like a war always has at least two sides. And both the US and the North Vietnamese have their ideological points of view on the war. There are substantial logistics lessons to be learned from the Vietnam War. As people know history repeats itself but we never learn from history. Maybe we don't want to learn from history not because we are stupid but because individual interests pay a more important role. One asks in history who built this building and the answer is it was built by king such and such or under president Kennedy but we never remember the brick layers and craftsmen who did the actual work if we are lucky we remember the architect such as Leonardo Davinchi or Frank Lloyd Wright. The same with the war we remember the generals and the minister of defense and the president but not the individual soldier who suffered and died in the battle field. Certainly this war was fought for different reasons on the two sides the North Vietnamese wanted victory for any price, even so the communist still to this day 2013 denied this fact and claim it was a fight for independence and nationalism. The US on the other side were fighting a war which was entirely supported by its people the anti war protests in the states made the US soldiers unappreciated and brand marked. How can you fight in a hostile country under the worst conditions without the moral support of your own people and a clear picture what are you fighting for.

Some understood that they are fighting against communism and to free the Vietnamese people. At the same time the South Vietnamese relied on the US to fight the war for them and they would be able to enjoy the victory and the way victory which was to be paved with great rewards for the South Vietnamese military and elite. Certainly many business people and military brass profited from the war time economy and only started to worry when the war almost reached Saigon. The Vietnamese refugee situation of those who escaped Vietnam in three major waves is another interesting logistics efforts which will be dealt with in a separate paper. There was the first wave which left Vietnam together with the US forces, there were 140,000 Vietnamese evacuated in April 1975 with "The Fall of Saigon". An estimated 10 million Vietnamese became refugees which was $55 \%$ of the entire population. .The second and often most tragic wave who escaped Vietnam by boat in the seventies and early eighties, these Vietnamese boat people greatly contributed to the US economy and finally the last wave which left Vietnam by airplane being sponsored by relatives living in the US who paid for their way out. These three waves had interesting logistics effort, especially the underground logistics network for boat people which often brought them to Thailand and finally to refugee camps in Malaysia. 
Figure 6: Military Logistics Functions

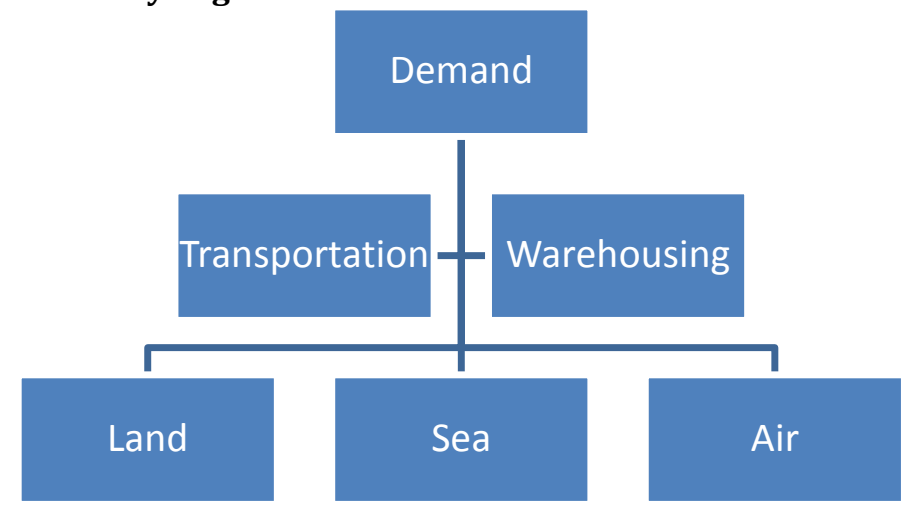

\section{Conclusion}

In conclusion one has to acknowledge that the North Vietnamese were very effective in its logistics effort during the Vietnam War. They made a lot out of the limited resources they had and were very effective. By definition a good (logistics) manager is one who most effectively manages limited resources. Bicycle porters on the Ho Chi Minh trailer against US airlift command and Bell helicopters. On the human side however one also has to admit that the North Vietnamese government won this war with its own people paying a high price. This was as often portrait by the Vietnamese a war of David fighting Goliath. The US had a very sophisticated war machinery with the latest technology. But this large footprint requires a lot of logistics support and infrastructure which has to be in place first to fight under extreme climate and terrain conditions. The US has not won a war since World War II, and should learn the lessons from Vietnam and its consecutive wars. Modern warfare may be like a computer game, but only during the early stages of the war when first strike is delivered. The US had air superiority during the Vietnam War and effective bases in neighboring Thailand. The US has not been effective in a ground war fought in the jungle and in urban warfare. The US also lacked the human intel (human intelligence) and understanding of the culture of the people. It is very difficult to fight an enemy you don't understand and who has different believes and values. Maybe this is one factor why the US could win in Germany as the Germans were very predictable and would follow a similar logic and rational, this again would be a topic for another paper. Another important thing on the Vietnam War was that it escalated and that the US made a sequence of wrong judgment and policy decisions. World War II was ended by bringing in the big gun the atomic bomb. In the Vietnam War the US had the weapon systems but did not want to bring them to bear. Carpet bombings of Hanoi in the early days would have stopped the war, but the US was afraid of the Chinese and Russian reaction. Maybe in retrospect loosing Vietnam was a small price to pay, particular as we see how Vietnam now is coming back as trading partner of the US and import ally in the ASEAN community. Remember that time heals all wounds. Those who cannot remember the past are condemned to repeat it. Santayana, George (1905) The Life of Reason, Volume 1

Figure 7: Logistics the life blood of war

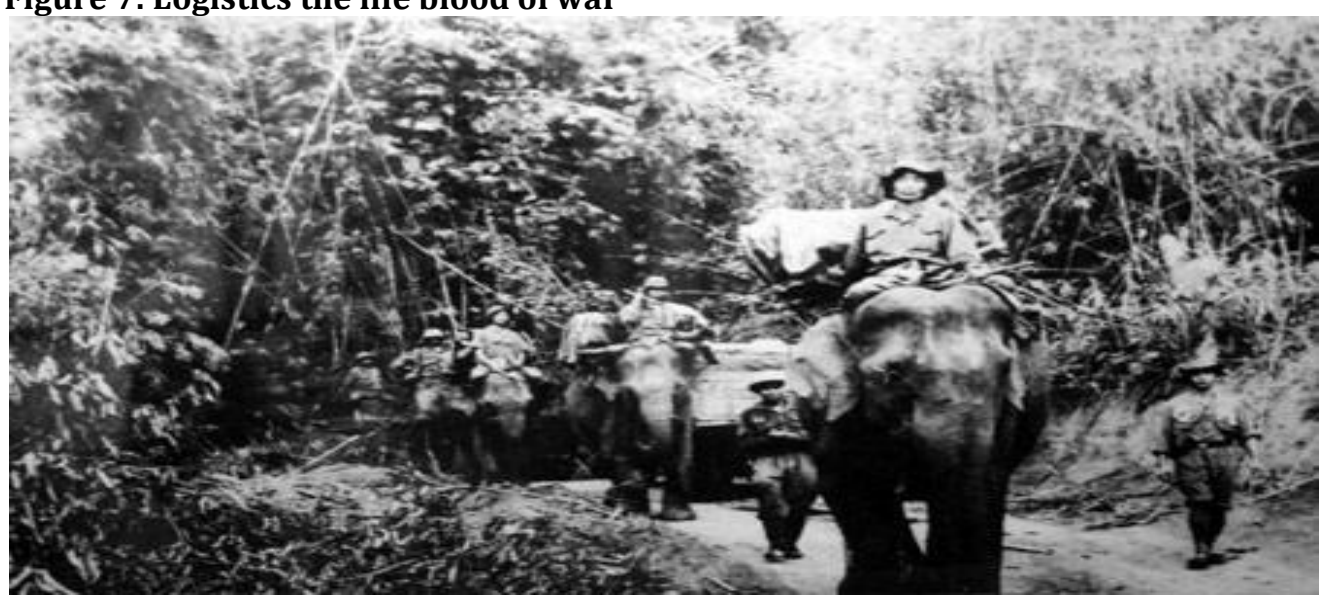


Acknowledgement: The author would like to acknowledge the Vietnam Veterans for their contributions to the war and this paper. He gained great inside into the logistics conditions during the war and what the situation was serving in country. A special heartfelt thank you to Mr. Tam Le from Ke Mon village near Hue, South Vietnam for which the author developed a deep appreciation and respect for a self-made business man who got his large family through both the first and second Indochina war and brought them to America to establish a network of family owned jewelry stores. The author would also like to thank the Vietnamese Viet Kio community of Houston Texas, USA from whom he gained valuable insights in the history of Vietnam.

\section{References}

Cutler, T. J. B. W. B. (1988). Coastal and Riverine Warfare in Vietnam. Naval Institute Press, Annapolis, Maryland.

Gargan, E. A. (2002). The River's Tale, A year on the Mekong. Alfred A. Knopf. New York, New York.

Henderson, J. (2008). Military Logistics Made Easy: Concept, Theory, and Execution. Author House. New York, New York.

Heiser, J. (1974). Logistic Support, Department of the Army, Washington, DC

Hooper, E. (1972). Mobility, Support Endurance - Naval Logistics Operations, Department of the Navy, Washington, DC.

Kane, T. (2001). Military Logistics and Strategic Performance. Rutledge, London.

Prados, J. (1998). The Blood Road. John Wiley and Sons. New York, New York.

Schaff, H. \& Fifield, R. (1963). The Lower Mekong: Challenge to Cooperation in Southeast Asia. D. Van Nostrand Company, Inc., Princeton, NJ. 